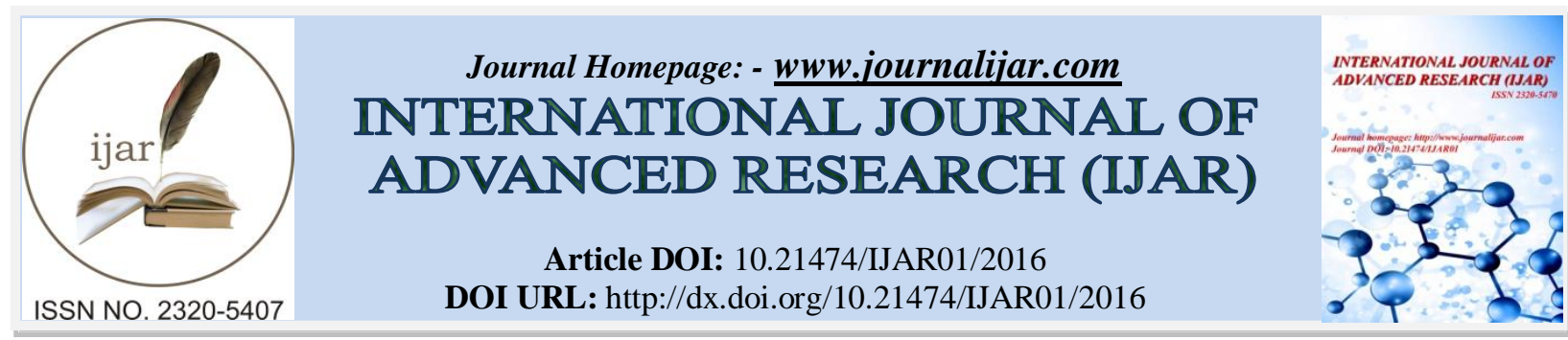

RESEARCH ARTICLE

\title{
EFFECT OF WASTE WATER ON GROUND GRANULATED BLAST FURNACE SLAG BASED CONCRETE.
}

Shashir N. Daule ${ }^{1}$ and Elisha D. Shinde ${ }^{2}$.

1. Assistant Professor, Department of Civil Engineering, P.D.V.V.PCollege of Engineering, Ahmednagar, India.

2. Lecturer, Department of Civil Engineering, G. H. Raisoni College of Engineering and Management, Ahmednagar, India.

\section{Manuscript Info}

Manuscript History

Received: 22 September2016

Final Accepted: 6 October 2016

Published: October 2016

Key words:-

Concrete, GGBS, Tap water, Waste

Water, etc.

\section{Abstract}

Water is a natural resource on which entire kingdom of flora and fauna depends. In recent decades depletion, wastage and pollution of this natural resource has been done on a large scale. Due to this, some areas had encountered with extreme drought conditions. This affects the construction industry and thus affects the economy of the country. Hence use of this water in efficient way has become a need. Thus Water in both form polluted and fresh water should be used to overcome the problem of water shortage.

The other problem is disposal of waste generated from the industries. The waste such as GGBS is generated from the steel industry. So use of this waste is also an important issues. In this paper comparative study has been made between, concrete casted by using waste water and tap water with GGBS in varying proportion as a replacement for cement.

Copy Right, IJAR, 2016,. All rights reserved.

\section{Introduction:-}

Water being a natural resource is being polluted by domestic waste, industrial waste etc. Hence study of the pollutants available in the polluted water is also very important. On the other hand GGBS, which is a pozzalonic material having ingredients similar to that of ordinary portland cement, but in little variation. In this paper GGBS has been used as a partial replacement for cement in concrete (M35), and concrete has been casted by using waste water and tap water. And comparison has been made between its strength parameters and other properties of concrete.

\section{Objectives of investigation:-}

Experiments were conducted on concrete prepared by partial replacement of cement by GGBS, ranging from $10 \%$ to $50 \%$ with an increment of $10 \%$. Thus replacing cement by GGBS concrete is casted by using tap water and waste water. The main objective of this investigation was to find out the effect of waste water on GGBS based concrete (i.ethe compressive strength, tensile strength and flexural strength) as well as to evaluate the possibility of using GGBS in concrete as a partial replacement for cement along waste water without sacrificing its strength.

Corresponding Author:- Shashir N. Daule. 
Following are the main objectives of the study:

1. To use GGBS as partial substitute for ordinary Portland cement along with waste water.

2. To determine the percentage of GGBS along with waste water which gives maximum strength when compared to the control mix concrete.

3. To study the effect of waste water on other properties of concrete such as its chemical properties of concrete.

\section{Materials used:-}

The material details are as follows:

\section{Cement:-}

Cement may be defined as binding substance capable of holding of solid matter together so as to act as a solid structure. The four major potential components are normally termed as tri-calcium silicate, Di-Calcium Silicate, Tri Calcium Aluminates and tetra calcium alumina ferrate.Cement used for the work was 53 grade (Birla) Ordinary Portland Cement confirming to IS 8112-1989.

\section{Fine aggregate:-}

Locally available sand from Mula River confirming to zone II with specific gravity 2.66 was used. All the test on fine aggregate was conducted as per Indian Standard Specification IS: 383-1970.

\section{Coarse aggregate:-}

Coarse aggregate used was $20 \mathrm{~mm}$ and less size having specific gravity 2.70. All the tests on coarse aggregate was conducted as per Indian Standard Specification IS: 383-1970.

\section{GGBS:-}

In this experiment GGBS is partially used as replacement for cement in M35 grade concrete. Chemical composition of GGBS is given as follows:

Table 1:- Physical Properties of GGBS

\begin{tabular}{|l|l|}
\hline Physical Property of GGBS & Value \\
\hline Specific Gravity & 2.43 \\
\hline Color & Off - White \\
\hline pH & 8.5 \\
\hline
\end{tabular}

Table 2:- Chemical Properties of GGBS

\begin{tabular}{|l|l|}
\hline Composition & Percentage (\%) \\
\hline $\mathrm{CaO}$ & $30-50$ \\
\hline $\mathrm{SiO}_{2}$ & $28-38$ \\
\hline $\mathrm{Al}_{2} \mathrm{O}_{3}$ & $8-24$ \\
\hline $\mathrm{MgO}$ & $1-18$ \\
\hline $\mathrm{Fe}_{2} \mathrm{O}_{3}$ & $0.9-1.2$ \\
\hline
\end{tabular}

Water:-

Sample 1 - The water used was potable, colorless and odorless that is free from organic impurities of any type (Tap Water)

Sample 2 - The water used was waste water obtained from natural stream polluted due waste discharged into it.

Table 3:- Properties of Waste Water:

\begin{tabular}{|l|l|l|}
\hline \multirow{2}{*}{ Property of Water } & Value & Tap Water \\
\cline { 2 - 3 } & Waste Water & $0.3 \mathrm{mg} / \mathrm{lit}$. \\
\hline Hardness & $712 \mathrm{ppm}$ & $29 \mathrm{mg} / \mathrm{lit}$ \\
\hline Alkalinity & $620 \mathrm{ppm}$ & $0.7 \mathrm{mg} / \mathrm{lit}$ \\
\hline Chloride Content & $157.27 \mathrm{ppm}$ & $82 \mathrm{mg} / \mathrm{lit}$ \\
\hline Total Dissolved Solids & $166 \mathrm{mg} / \mathrm{lit}$. & $35 \mathrm{mg} / \mathrm{lit}$ \\
\hline Dissolved Solids & $90 \mathrm{mg} / \mathrm{lit}$. & $0.56 \mathrm{mg} / \mathrm{lit}$ \\
\hline Suspended Solids & $56 \mathrm{mg} / \mathrm{lit}$. & \\
\hline
\end{tabular}




\begin{tabular}{|l|l|l|}
\hline Volatile Solids & $20 \mathrm{mg} / \mathrm{lit}$. & - \\
\hline BOD & $52 \mathrm{mg} / \mathrm{lit}$ & $0.9 \mathrm{mg} / \mathrm{lit}$ \\
\hline COD & $122 \mathrm{mg} / \mathrm{lit}$ & - \\
\hline Sludge Volume Index & 178.57 & - \\
\hline Sulphate Content & $129 \mathrm{mg} / \mathrm{lit}$ & $25 \mathrm{mg} / \mathrm{lit}$ \\
\hline Fluoride Content & $8.46 \mathrm{mg} / \mathrm{lit}$ & $0.2 \mathrm{mg} / \mathrm{lit}$ \\
\hline
\end{tabular}

\section{Experimental work and test:-}

\section{Mix Design:-}

Mix designwas carried out for M35 grade of concrete by using IS 10262:2009, which resulted to a mix proportion of 1:1.52:2.04 with water cement ratio of 0.42 . The replacement of cement by GGBS was $10 \%$ to $50 \%$ at an interval of $10 \%$ each, casted by using waste water and tap water.

\section{Preparation of Test Specimens:-}

Concrete mixture was done according to the mix design. The total mixing time was 10 minutes then the samples were casted and left for 24 hours. After that, samples were demoulded and placed in the curing tank 7 days and 28 days.

Table 4:- Specimens Dimensions.

\begin{tabular}{|l|l|l|}
\hline Properties studied & Specimen shape & $\begin{array}{l}\text { Sizes of specimens } \\
(\mathbf{m m})\end{array}$ \\
\hline Compressive strength & Cube & $150 \times 150 \times 150$ \\
\hline Flexural strength & Beams & $100 \times 100 \times 500$ \\
\hline Split tensile strength & Cylinders & $150 \times 300$ \\
\hline Pull out Strength & Cube & $150 \times 150 \times 150$ \\
\hline Water absorption test & Cube & $150 \times 150 \times 150$ \\
\hline
\end{tabular}

\section{Results and Discussion:-}

In this study, testswere conducted on harden concrete by using Compressive Testing Machine(CTM) of capacity $3000 \mathrm{KN}$ and Universal Testing Machine (UTM) of capacity $600 \mathrm{KN}$ as per IS 516:1959.

\section{Compressive Strength Test results (IS 516:1959):-}

According to IS: $516: 1959$, the cubes of size $150 \mathrm{~mm} \times 150 \mathrm{~mm} \times 150 \mathrm{~mm}$ were prepared for the compression test. According to IS: 10086-1982, this cubes were placed in machine in such a manner that the load is applied perpendicular to the surface. The rate of loading is uniform and failure (crushing) load is noted.

Table 6:- Experimental Test Results For Compressive Strength.

\begin{tabular}{|l|l|l|}
\hline \multirow{2}{*}{$\%$ replacement of cement by GGBS } & \multicolumn{2}{|l|}{$\begin{array}{l}\text { Compressive Strength in MPa } \\
\text { ( 28 Days ) }\end{array}$} \\
\cline { 2 - 3 } & Tap Water & Waste Water \\
\hline 0 & 41.28 & - \\
\hline 10 & 43.87 & 45.77 \\
\hline 20 & 50.43 & 55.63 \\
\hline 30 & 53.54 & 44.58 \\
\hline 40 & 50.711 & 43.23 \\
\hline 50 & 37.19 & 35.76 \\
\hline
\end{tabular}

It is clear from table 6, compressive strength for 30\% replacement of GGBS casted using tap water showed good results as compared to conventional mix concrete. In case of Waste water $20 \%$ replacement showed better results.

\section{Results of Spilt Tensile Strength Test:-}

Split tensile strength of cylinder specimens is determined by placing between the two plates of Compression Testing Machine, Plywood strips of $3 \mathrm{~mm}$ thick, $25 \mathrm{~mm}$ wide and $300 \mathrm{~mm}$ long, were placed between the plates and surface of the concrete specimens. 
According to IS: 5816:1999 for determining split tensile strength cylinder specimens of size $150 \mathrm{~mm}$ in diameter and $300 \mathrm{~mm}$ in are horizontally placed between the two plates of Compression Testing Machine. In these tests, compressive force is applied to a concrete specimen in such a way that the specimen fails due to tensile stresses induced in the specimen.

It is clear from table 7 (given below), Split Tensile strength for concrete casted using tap water along with $40 \%$ replacement of cement by GGBS showed good value as compared to control concrete for 28 days. In case of waste water $20 \%$ replacement showed good values as compared to conventional concrete.

Table 7:- Experimental Test Results For Split Tensile Strength.

\begin{tabular}{|l|l|l|}
\hline \multirow{2}{*}{$\%$ Replacement of cement by GGBS } & \multicolumn{2}{l|}{$\begin{array}{l}\text { Spilt Tensile Strength in MPa } \\
\text { (28 Days ) }\end{array}$} \\
\cline { 2 - 3 } & Tap Water & Waste Water \\
\hline 0 & 4.16 & - \\
\hline 10 & 4.341 & 3.60 \\
\hline 20 & 4.78 & 4.286 \\
\hline 30 & 4.68 & 3.92 \\
\hline 40 & 4.19 & 3.68 \\
\hline 50 & 3.78 & 3.25 \\
\hline
\end{tabular}

Results of Flexural Strength Test: (IS: 516:1959):-

Beams of size $100 \mathrm{~mm}$ X $100 \mathrm{~mm}$ X $500 \mathrm{~mm}$ were prepared and cured for 28 days and tested under two-point loading in beam reaction apparatus. The load as increased until the specimen failed and the failure load is recorded. The test results obtained are as follows:

Table 8:- Experimental Test Results For Flexural Strength.

\begin{tabular}{|l|l|l|}
\hline \multirow{2}{*}{$\%$ Replacement of cement by GGBS } & $\begin{array}{l}\text { Flexural Strength in MPa } \\
\text { ( 28 Days ) }\end{array}$ \\
\cline { 2 - 3 } & Tap Water & Waste Water \\
\hline 0 & 4.04 & - \\
\hline 10 & 4.31 & 4.25 \\
\hline 20 & 4.36 & 4.58 \\
\hline 30 & 4.57 & 4.336 \\
\hline 40 & 4.16 & 4.01 \\
\hline 50 & 3.88 & 3.92 \\
\hline
\end{tabular}

It is clear from table 8, flexural strength for concrete casted using tap water along with $20 \%$ replacement of cement by GGBS showed good value as compared to control concrete for 28 days. In case of waste water $20 \%$ replacement showed good values as compared to conventional concrete.

\section{Results of Alkalinity Test:-}

For conducting the alkalinity test specimen are cured for 60 days are taken. The specimens were oven dried at $105^{\circ} \mathrm{C}$ for 24 hours. Mortar was separated from the dry concrete by breaking down the dry specimen. The mortar was grinded into powder form. The powdered mortar sieved in $90 \mu$ and $10 \mathrm{gm}$ of sample was diluted in 50ml distilled water and stirred it completely. Then with $\mathrm{pH}$ paper was immersed, with the help of $\mathrm{pH}$ scale, $\mathrm{pH}$ was noted. Then in same solution glass electrode was immersed and with the help of $\mathrm{pH}$ meter the $\mathrm{pH}$ value was noted.

Table 9:- Experimental Test Results for Alkalinity Test.

\begin{tabular}{|l|l|l|l|l|}
\hline \multirow{2}{*}{$\begin{array}{l}\text { \% Replacement of cement by } \\
\text { GGBS }\end{array}$} & $\begin{array}{l}\text { pH Value } \\
\text { (pH Paper) }\end{array}$ & \multicolumn{2}{l|}{$\begin{array}{l}\text { pH Value } \\
\text { (pH Meter) }\end{array}$} \\
\cline { 2 - 5 } & Tap Water & Waste Water & Tap Water & Waste Water \\
\hline $0 \%$ & 10 & - & 9.46 & - \\
\hline $10 \%$ & 10 & 10.5 & 9.84 & 10.46 \\
\hline $20 \%$ & 10 & 10.5 & 10.06 & 10.53 \\
\hline $30 \%$ & 10 & 10.5 & 10.19 & 10.67 \\
\hline $40 \%$ & 10 & 10.5 & 10.34 & 10.76 \\
\hline $50 \%$ & 10 & 10.5 & 10.42 & 10.81 \\
\hline
\end{tabular}


It is clear from table 9, alkalinity of GGBS based casted by using tap water ranges from $9-10.5$. In case of waste water casted concrete $\mathrm{pH}$ value is more as compared to tap water casted concrete.

\section{Results of Water Absorption (Porosity) Test:-}

Water absorption test or the porosity test was carried to find out the percentage water absorption. The test results obtained are as follows:

Table 10:- Experimental Test Results for Water Absorption Test.

\begin{tabular}{|l|l|l|}
\hline \multirow{2}{*}{$\%$ Replacement of cement by GGBS } & \% Water absorption \\
\cline { 2 - 3 } & Tap water & Waste Water \\
\hline 0 & 4.16 & - \\
\hline 10 & 3.89 & 3.94 \\
\hline 20 & 3.54 & 3.75 \\
\hline 30 & 3.33 & 4.26 \\
\hline 40 & 4.085 & 4.53 \\
\hline 50 & 4.33 & 4.81 \\
\hline
\end{tabular}

It is clear from table 10, water absorption of concrete reduces as the percentage of GGBS in concrete increases. For tap water casted concrete along with GGBS, $30 \%$ replacement showed less value. For waste water casted concrete along GGBS, $20 \%$ replacement showed less value.

\section{Results of Carbonation Test:-}

Carbonation test is carried out to determine the depth of concrete affected due to combined attack of atmospheric carbon dioxide and moisture causing a reduction in level of alkalinity of concrete. A spray of $0.2 \%$ solution of phenolphthalein is used as indicator of concrete. The change of color of concrete to pink indicates that the concrete is in good health.

\section{Results of Rebound Hammer test:-}

This test is used to find out the compressive strength of concrete by using rebound hammer as per IS: 13311 (Part II)-1992. The rebound of an elastic mass depends on the hardness of the surface against which its mass strikes. The rebound value is read from the graduated scale and is designated as the rebound number or rebound index. The compressive strength can be read directly from the graph provided on the body of hammer or with the help of digital display which gives compressive strength. 3 cubes of each variation were casted for the conduction of test and cured for 28 days under water. Rebound Hammer test results obtained are given as follows:

Table 11:- Experimental Test Results for Rebound Hammer Test.

\begin{tabular}{|l|l|l|}
\hline \multirow{2}{*}{$\begin{array}{l}\text { \% replacement of cement by } \\
\text { GGB }\end{array}$} & $\begin{array}{l}\text { Compressive Strength } \\
\text { (MPa) }\end{array}$ & Waste Water \\
\cline { 2 - 3 } & Tap Water & - \\
\hline $0 \%$ & 42.98 & 43.75 \\
\hline $10 \%$ & 43.52 & 45.42 \\
\hline $20 \%$ & 46.33 & 41.17 \\
\hline $30 \%$ & 49.5 & 40.38 \\
\hline $40 \%$ & 42.28 & 39.99 \\
\hline $50 \%$ & 40.75 & \\
\hline
\end{tabular}

Results for Ultrasonic Pulse Velocity Test:-

This test is done to assess the quality of concrete by ultrasonic pulse velocity method as per IS: 13311 (Part I)-1992. This method consists of measuring the time of travel of an ultrasonic pulse passing through the concrete being tested. The ultrasonic pulse velocity depends on the density and elastic properties of material being tested. Comparatively higher velocity is obtained when concrete quality is good in terms of density, uniformity; homogeneity etc. 3 cubes of each variation were casted for the conduction of test and cured for 28 days under water. 
Table 12:- Experimental Test Results for Ultrasonic Pulse Velocity Test (Tap Water).

\begin{tabular}{|c|c|c|}
\hline \% replacement of cement by GGBS & $\begin{array}{l}\text { Pulse Velocity } \\
(\mathrm{Km} / \mathrm{sec} .)\end{array}$ & Concrete Quality \\
\hline $0 \%$ & 3.52 & \multirow[t]{5}{*}{ Good to very good, slight porosity may exist } \\
\hline $10 \%$ & 3.56 & \\
\hline $20 \%$ & 3.63 & \\
\hline $30 \%$ & 3.78 & \\
\hline $40 \%$ & 3.56 & \\
\hline $50 \%$ & 3.43 & Satisfactory but loss of integrity is suspected \\
\hline
\end{tabular}

Table 13:- Experimental Test Results for Ultrasonic Pulse Velocity Test (Waste Water).

\begin{tabular}{|l|l|l|}
\hline $\begin{array}{l}\text { \% replacement of cement by } \\
\text { GGBS }\end{array}$ & $\begin{array}{l}\text { Pulse Velocity } \\
(\mathbf{K m} / \mathbf{s e c} .)\end{array}$ & Concrete Quality \\
\hline $10 \%$ & 3.35 & $\begin{array}{l}\text { Satisfactory but loss of integrity is } \\
\text { suspected }\end{array}$ \\
\hline $20 \%$ & 3.51 & $\begin{array}{l}\text { Good to very good, slight porosity may } \\
\text { exist }\end{array}$ \\
\cline { 1 - 2 } $30 \%$ & 3.23 & $\begin{array}{l}\text { Satisfactory but loss of integrity is } \\
\text { suspected }\end{array}$ \\
\hline $40 \%$ & 3.22 & \\
\hline
\end{tabular}

\section{Conclusion:-}

Based on the experimental work conducted, the following conclusions are drawn.

1. $30 \%$ replacement of cement by GGBS in concrete casted by using tap water, strength increases by $29 \%$, for waste water casted concrete $20 \%$ replacement is the optimum replacement of GGBS for cement in concrete. The strength increases by $34 \%$.

2. $30 \%$ replacement of cement by GGBS in concrete casted by using tap water, split tensile strength increases by $12.5 \%$, for waste water casted concrete $20 \%$ replacement is the optimum replacement of GGBS for cement in concrete. The strength increases by $3 \%$.

3. $40 \%$ replacement of cement by GGBS in concrete casted by using tap water, flexural strength increases by $3 \%$, for waste water casted concrete $30 \%$ replacement is the optimum replacement of GGBS for cement in concrete. The strength increases by $7 \%$.

4. The $\mathrm{pH}$ of concrete along with GGBS and casted using tap water shows pHvalue ranging between $9-10.5$. In case of GGBS based concrete casted by using waste water shows pH value ranging from $10-10.81$. The specimens were more alkaline hence has more resistance for corrosion.

5. For Water absorption test, in case of tap water casted concrete as percentage of GGBS increases water absorption reduces up to $30 \%$ as the concrete is more dense. In case of GGBS based concrete casted using waste water up to $20 \%$ replacement value of water absorption is less.

6. Increases of GGBS in concrete increases the workability of concrete. As GGBS gives out water (GGBS doesnot absorb water).

7. For carbonation test the color of concrete surface after spraying phenolphthalein indicator changed purple - pink which indicated that concrete was not affected by the atmospheric carbon dioxide.

8. For ultrasonic pulse velocity test, $30 \%$ replacement has pulse velocity is greater than $3.5 \mathrm{Km} / \mathrm{sec}$ in case of tap water casted concrete. In case of waste water casted concrete $20 \%$ replacement GGBS partially replaced for cement pulse velocity is greater than $3.5 \mathrm{Km} / \mathrm{sec}$, but for rest of specimen, pulse velocity is less than 3.5 $\mathrm{Km} / \mathrm{sec}$.

9. Hence from the above results we can conclude that $30 \%$ is the optimum replacement of GGBS in case of tap water casted concrete. In case of GGBS based concrete casted by using waste water with the specifications given above give optimum results for $20 \%$ replacement. So GGBS along with waste water can be used for $20 \%$ replacement

10. Use of waste water and GGBS in concrete is a good option for eco-friendly development. 


\section{Acknowledgement:-}

All the experimental work was carried out using the facilities in Civil Engineering Department laboratory of P.D.V.V.P. COE, Ahmednagar. I wish to thank Prof. U.R. Kawade, (HOD), Prof. P.B. Autade, ME Co-ordinator and Prof. S. N. Daule, Project Guide for their valuable suggestions and all staff members for their valuable support.

\section{References:-}

1. Huiwen Wan, ZhongheShui, Zongshou Lin, Analysis of geometric characteristics of GGBS and their influences on cement propertiesCement and Concrete research 34 (2004) 133-137

2. Folarin T. Olorunsogo- and Peter J. Wainwrighe,Effect of GGBFS Particle-Size Distribution on Mortar Compressive Strength, ASCE

3. W. C Jau, D, S, Tsay, A study of the basic engineering properties of slag cement concrete and its resistance to seawater corrosion, Cem. Concr. Res, 28 (10) (1998) 1363 - 1371

4. K. Tan X. Pu, Strengthing, Effect of finely ground fly ash, granulated blast furnace slag, and their combination, Cem. Concr. Res. 28 (12) (1998) 1819 - 1826

5. Mehta P K. Pozzolanic and cementitious by-products as mineral admixtures for concrete - a critical review, SP-79 ACI; 1983 P. 1-48

6. Malhotra V M, Mehta P K. Pozzolanic and cementitious materials. Advances in concrete Technology. London; Gordon and Breach; 1996

7. Roy D M, Idorn G M. Hydration, structure, and properties of blast - furnace slag cements, mortars, and concrete. J Am Concrete Inst. 1982; 79:445-57

8. Ganesh Babu K, Sree Rama Kumar V, Efficiency of GGBS in concrete, Cement Concrete Res. 2000;1031-6

9. ACI Committee 233. Ground granulated blast-furnace slag as a cementitious constituent in concrete, ACI 233R-95, American Concrete Institute; 1995

10. N Nakamura, M Sakai, R.N. Swamy, Effect of slag fineness on the development of concrete strength and microstructure, ACI SP 132, Detroit (1992) 1343-1365

11. J. W. Meusel, J.H. Rose, Production of Granulated blast furnace slag at sparrows point and the workability and strength potential of concrete incorporating the slag, ACI SP 79, Detroit (1983) 867-890

12. Indian Standard code of practice for plain and Reinforced Concrete, IS456:2000, Bureaue of Indian Standards, New Delhi.

13. M.S.Shetty, Concrete Technology Theory and Practice (S.Chand and Company Ltd.New Delhi, 2006)

14. Method of tests for strength of concrete, IS 516:1959, Bureau of Indian Standards, New Delhi.

15. Splitting tensile strength concrete method of test, IS5816:1999, Bureau of Indian Standards, New Delhi.

16. Recommended guidelines of concrete mix design, IS 10262:1982, Bureau of Indian Standards, New Delhi. 